\title{
Soft Tissue Sarcoma of the Abdomen and Thoracic Visceral Organs pT4b TNM
}

\section{Finding v8}

National Cancer Institute

\section{Source}

National Cancer Institute. Soft Tissue Sarcoma of the Abdomen and Thoracic Visceral

Organs pT 4b TNM Finding v8. NCI Thesaurus. Code C136741.

Soft tissue sarcoma of the abdomen and thoracic visceral organs with multifocal involvement (three to five sites). (from AJCC 8th Ed.) 